\title{
FAKTOR-FAKTOR KENDALA PENGELOLAAN KELAS PADA MATA PELAJARAN TEORI DI SMKN JURUSAN TEKNIK BANGUNAN TAHUN AJARAN 2011/2012
}

\author{
Ema Sonia Amelinda, Tuti Iriani, Amos Neolaka
}

\begin{abstract}
This research aims to determine the constraint factors affecting the class management of courses content theory in Vocational High School Majoring in Building Construction for the students of Building Construction Education Study Program State University of Jakarta who attend the Teaching Apprenticeship Program (PPL). This research placed in eight vocational schools majoring in Building Construction in March until May 2012.

The method used in this research is surveying method. The population in this research is 30 students of Building Construction Education Study Program Department of Civil Engineering Faculty of Engineering State University of Jakarta who teach the class content theory during the PPL. The number of samples is 28 students who are determined using simple random sampling. The additional data to strengthen this research is gained from 75 students (from 3 classes) which are established using purposive sampling. The instrument used in this research is using questionnaire to collect the data about constraint factors affecting the class management to the PPL students. Based on the calculation, we get the value of reliability $r$ is 0.97 for the questionnaire spread both for the students and teachers in vocational high school.

Based on the answers of the respondent from the PPL teachers and students, we can see that the students have more honest answer regarding the questionnaire. Constraint factors affecting the class management from the student's answers to the teacher's attitude indicator has the average value of 3.32. Constraint factors affecting the class management from the student's answers to the student's indicator has the average value of 3.04 . Constraint factors affecting the class management from the student's answers to the classroom management and teaching visual aids indicator has the average value of 2.96. And constraint factors affecting the class management from the student's answers to the class discipline indicator has the average value of 2.59 .

Based on this research we can conclude that teacher's attitude taken into first place for the constraint factors affecting the class management shown by the highest average score 3.32. It is caused by a minimum practice of teaching to the PPL students especially about class management and an ineffectiveness of briefing before PPL.
\end{abstract}

Keywords: constraint factors, management of courses

\begin{tabular}{|l|r|r|}
\hline Ema Sonia Amelinda & Dr. Tuti Iriani, M.Si & Prof. Dr. Amos Neolaka \\
Alumni Jurusan Teknik Sipil & Jurusan Teknik Sipil & Jurusan Teknik Sipil \\
Fakultas Teknik & Fakultas Teknik \\
Universitas Negeri Jakarta, 13220 & $\begin{array}{c}\text { Fniversitas Negeri Jakarta, 13220 } \\
\text { email :t_iriani@yahoo.com }\end{array}$ & $\begin{array}{l}\text { Universitas Negeri Jakarta, 13220 } \\
\text { email:amos_neolaka@yahoo.com }\end{array}$ \\
\hline
\end{tabular}

Perbedaan Pembelajaran Menggunakan Aplikasi Multimedia Presentasi dengan Pembelajaran Media Program Pengolah Kata terhadap Hasil Belajar Mata Pelajaran Teori Kejuruan Teknik Furnitur (Studi pada Mata Pelajaran Kejuruan Furnitur Kelas XI SMKN 52 Jakarta) Hadi Mukhlish, T uti Iriani, R. Eka Murtinugraha 


\section{PENDAHULUAN}

Dalam Pedoman PPL UNJ 2010 tujuan dari pelaksanaan PPL adalah agar mahasiswa dapat mengaplikasikan secara terpadu seluruh pengalaman belajar yang didapat selama mengikuti pendidikan di Universitas Negeri Jakarta. PPL juga merupakan suatu program ajang pelatihan untuk menerapkan berbagai pengetahuan ,sikap, dan keterampilan dalam rangka pembentukan profesionalisme guru yang sesuai dengan tuntutan perkembangan ilmu pengetahuan dan teknologi (IPTEK) serta tuntutan UndangUndang Pendidikan Nasional.

Menurut Djamarah (2010: 10), proses belajar mengajar merupakan inti dari proses pendidikan formal dengan guru sebagai pemeran utama. Guru sangat menentukan suasana belajar mengajar di dalam kelas. Guru yang kompeten akan lebih mampu dalam menciptakan lingkungan belajar yang efektif dan efisien di dalam kelas, sehingga hasil belajar siswa berada pada tingkat yang optimal. Keberhasilan tersebut, dipengaruhi banyak faktor terutama terletak pada pengajar (guru) dan yang diajar (siswa), yang berkedudukan sebagai pelaku dan subyek dalam proses tersebut.

Akan tetapi pada kenyataannya-berdasarkan keluhan dari beberapa mahasiswa PPL semester 096-mahasiswa PPL sangat mengalami kesulitan dalam pelaksanaan pengelolaan kelas di sekolah mereka masing-masing. Hal ini sesuai dengan pernyataan Sunaryo (1989:62) bahwa manajemen kelas merupakan masalah tingkah laku yang kompleks. Guru menggunakan manajemen kelas untuk menciptakan dan mempertahankan kondisi kelas sedemikian rupa sehingga siswa dapat mencapai tujuan pengajaran secara efisien dan memungkinkan mereka dapat belajar.

Berdasarkan pemaparan di atas, maka penulis tertarik untuk mengadakan penelitian tentang faktor kendala pengelolaan kelas pada mata pelajaran teori di SMKN Jurusan Teknik Bangunan Tahun Ajaran 2011/2012. Tujuan penelitian ini adalah untuk mengetahui faktor-faktor kendala pengelolaan kelas pada mata pelajaran teori di SMKN Jurusan Teknik Bangunan Tahun Ajaran 2011/2012. Penelitian ini dilakukan di 8 SMKN tempat mahasiswa melakukan praktek mengajar pada mata pelajaran yang bersifat teori pada Jurusan Teknik Bangunan yaitu : SMKN 1, SMKN 4, SMKN 52, SMKN 26, SMKN 58, SMKN 56, SMKN 35 dan SMKN 1 Cibinong. Waktu pelaksanaan penelitian ini dilaksanakan pada Semester 096/Genap Tahun Akademik 2011/2012 pada bulan Januari - Juni 2012.

Jenis penelitian yang digunakan dalam penelitian ini adalah penelitian deskriptif dengan metode survei. Populasi dari penelitian ini adalah mahasiswa/i PPL Program Studi S1 Pendidikan Teknik Bangunan Program Studi Teknik Sipil Universitas Negeri Jakarta yang mengajar pada mata pelajaran bersifat teori di SMKN semester 096/Genap sebanyak 30 mahasiswa. Sampel yang digunakan dalam penelitian ini menggunkan teknik random sampling dengan galat kesalahan $5 \%$ untuk menentukan jumlah sample responden mahasiswa. Ditentukan sample mahasiswa berjumlah 28 mahasiswa. Detail jumlah sampel yang digunakan dapat dilihat pada tabel berikut.

Tabel 1. Jumlah Sampel Penelitian 


\begin{tabular}{|c|c|}
\hline Mata Pelajaran bersifat Teori & Sampel Penelitian \\
\hline IBB & 4 \\
\hline Menggambar Teknik & 10 \\
\hline Statika & 5 \\
\hline Rencana Anggaran Bangunan (RAB) & 4 \\
\hline Kesehatan dan keselamatan kerja (K3) & 5 \\
\hline JUMLAH & 28 Mahasiswa \\
\hline
\end{tabular}

Sedangkan teknik pengambilan jumlah sampel untuk responden siswa menggunakan teknik purposive sample yaitu sampel bertujuan, yang dilakukan dengan cara mengambil subjek didasarkan atas adanya tujuan tertentu. Teknik ini dilakukan karena beberapa pertimbangan, yaitu adanya keterbatasan waktu, tenaga, dan dana sehingga tidak dapat mengambil sampel yang besar dan jauh. (Suharsimi 2010:183). Ditentukan jumlah sampel siswa berjumlah 75 responden siswa.

Data yang dibutuhkan dalam penelitian ini diperoleh melalui sebuah instrumen. Instrumen penelitian yang digunakan dalam penelitian ini adalah berbentuk instrument non-tes. Angket ini disusun berdasarkan kisi-kisi yang telah dibuat. Angket ini berisi pertanyaan untuk menjaring tentang faktor-faktor kendala pengelolaan kelas.

\section{METODE}

Prosedur atau langkah-langkah yang ditempuh dalam pembuatan kuesioner adalah sebagai berikut :

a. Menentukan indikator-indikator yang menjadi dasar dalam penyusunan butir-butir pernyataan yang dan membuat kisi-kisi instrumen penelitian.

b. Menyusun rancangan kuesioner kemudian dikonsultasikan dengan dosen pembimbing untuk diberikan saran, pendapat, dan perbaikan. Kemudian dibuat kuesioner yang sebenarnya. Angket kuesioner tersebut berisi data responden dan pertanyaan-pertanyaan. Kedua alat pengumpulan data tersebut digunakan dalam penelitian ini. Pengisiannya dapat dilakukan dengan cara mengisi dan membubuhkan tanda check list $(\sqrt{ })$ pada kolom yang tersedia. Dalam setiap butir pertanyaan responden dapat memilih salah satu dari 5 alternatif jawaban yang disediakan. Dari kelima alternatif jawaban tersebut untuk pernyataan positif masing-masing diberi skor 5 untuk selalu, 4 untuk sering, 3 untuk ragu-ragu, 2 untuk kadang-kadang, dan 1 untuk tidak pernah, dan untuk pernyataan negatif diberi skor 5 untuk tidak pernah, 4 untuk kadang-kadang, 3 untuk ragu-ragu, 2 untuk sering, dan 1 untuk selalu.

c. Melakukan uji coba (pre-test) kepada 10 responden untuk menguji validitas dan reliabilitas dari instru-

Perbedaan Pembelajaran Menggunakan Aplikasi Multimedia Presentasi dengan Pembelajaran Media Program Pengolah Kata terhadap Hasil Belajar Mata Pelajaran Teori Kejuruan Teknik Furnitur (Studi pada Mata Pelajaran Kejuruan Furnitur Kelas XI SMKN 52 Jakarta) 
men penelitian. Setelah dilakukan analisis hasil uji coba diperoleh tingkat validitas, diperoleh 6 butir pernyataan tidak valid dari 40 butir pernyataan untuk angket mahasiswa, dan 9 butir pernyataan tidak valid dari 40 butir pernyataan untuk angket siswa. Dari pretest yang telah dilakukan, kedua angket meiliki nilai reliabilitas yang sama yaitu diperoleh $\left(r_{x x}\right)=0,97$. Dengan melihat nilai $r_{x x}=0,97$, maka dapat dikatakan bahwa nilai tersebut memiliki nilai reliabilitas tinggi, karena 0,97 terletak antara $0,80-1,00$.

d. Setelah instrumen tersebut dinyatakan valid dan reliabel, selanjutnya dilakukan penelitian yang sebenarnya terhadap sampel yang dijadikan responden.

Tabel 2. Kisi-kisi Instrumen Penelitian

\begin{tabular}{|c|c|c|c|c|}
\hline \multicolumn{5}{|c|}{ Kisi-Kisi Faktor Kendala Pengelolaan Kelas } \\
\hline Variabel & Indikator & Sub Indikator & No. Soal & $\begin{array}{l}\text { Jumlah } \\
\text { Butir }\end{array}$ \\
\hline \multirow{18}{*}{ 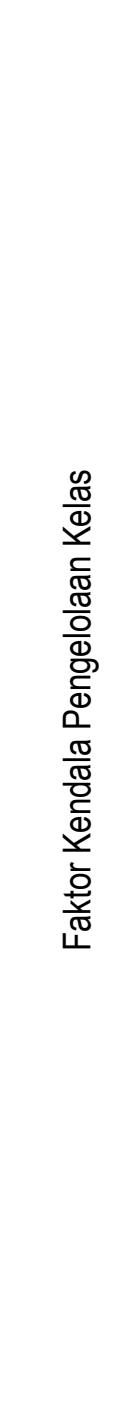 } & \multirow{5}{*}{ Sikap Guru } & - Guru yang bersifat hangat dan antusias & $1,2,3,4,5,6,7$ & 7 \\
\hline & & - Guru yang mampu memerikan tantangan & $8,9,10,11$ & 4 \\
\hline & & - Guru yang mampu bersikap luwes & $12,13,14$ & 3 \\
\hline & & $\begin{array}{l}\text { - Guru memberikan penekanan pada hal } \\
\text { positif }\end{array}$ & $15,16,17$ & 3 \\
\hline & & - Penanaman disiplin diri & 18,19 & 2 \\
\hline & \multirow{6}{*}{ Sikap Siswa } & $\begin{array}{l}\text { - Siswa diberi kesempatan untuk ikut dalam } \\
\text { proses perencanaan kegiatan }\end{array}$ & 20 & 1 \\
\hline & & $\begin{array}{l}\text { - Memberi kesempatan siswa untuk } \\
\text { mengatur disiplin kelas saat guru } \\
\text { berhalangan hadir }\end{array}$ & 21 & 1 \\
\hline & & - Mengadakan piket kelas & 22,23 & 2 \\
\hline & & $\begin{array}{l}\text { - Menetapkan tata tertib dan disiplin kelas } \\
\text { bersama siswa }\end{array}$ & 24 & 1 \\
\hline & & $\begin{array}{l}\text { - Siswa diberi kesempatan dalam pembagian } \\
\text { tugas-tugas untuk kepentingan kelas }\end{array}$ & 25 & 1 \\
\hline & & $\begin{array}{l}\text { - Mengembangkan kerja sama siswa dalam } \\
\text { setiap kegiatan untuk kepentingan kelas }\end{array}$ & 26 & 1 \\
\hline & \multirow{3}{*}{$\begin{array}{l}\text { Penataan } \\
\text { Ruang dan } \\
\text { Alat } \\
\text { Pengajaran }\end{array}$} & - Penataan tempat duduk siswa & $27,28,29$ & 3 \\
\hline & & - Media/sumber pengajaran & 30,31 & 2 \\
\hline & & - Ventilasi dan tata cahaya & 32,33 & 2 \\
\hline & \multirow{4}{*}{ Disiplin kelas } & - Bentuk pelanggaran & 34 & 1 \\
\hline & & - Masalah disiplin kelas & $35,36,37,38$ & 4 \\
\hline & & - Pendekatan pengelolaan disiplin & 39 & 1 \\
\hline & & - Tindakan pencegahan & 40 & 1 \\
\hline
\end{tabular}

HASIL DAN PEMBAHASAN

Berdasarkan perhitungan data tentang diketahui bahwa: 
a. Nilai rerata untuk indikator guru (terkait mahasiswa sebagai guru PPL) pada hasil angket siswa mempunyai nilai sebesar 3,32.

b. Nilai rerata untuk indikator siswa pada hasil angket siswa mempunyai nilai sebesar 3,04.

c. Nilai rerata untuk indikator penataan ruang dan alat pengajaran pada hasil angket siswa mempunyai nilai sebesar 2,96.

d. Nilai rerata untuk indikator disiplin kelas pada hasil angket siswa mempunyai nilai sebesar 2,59.

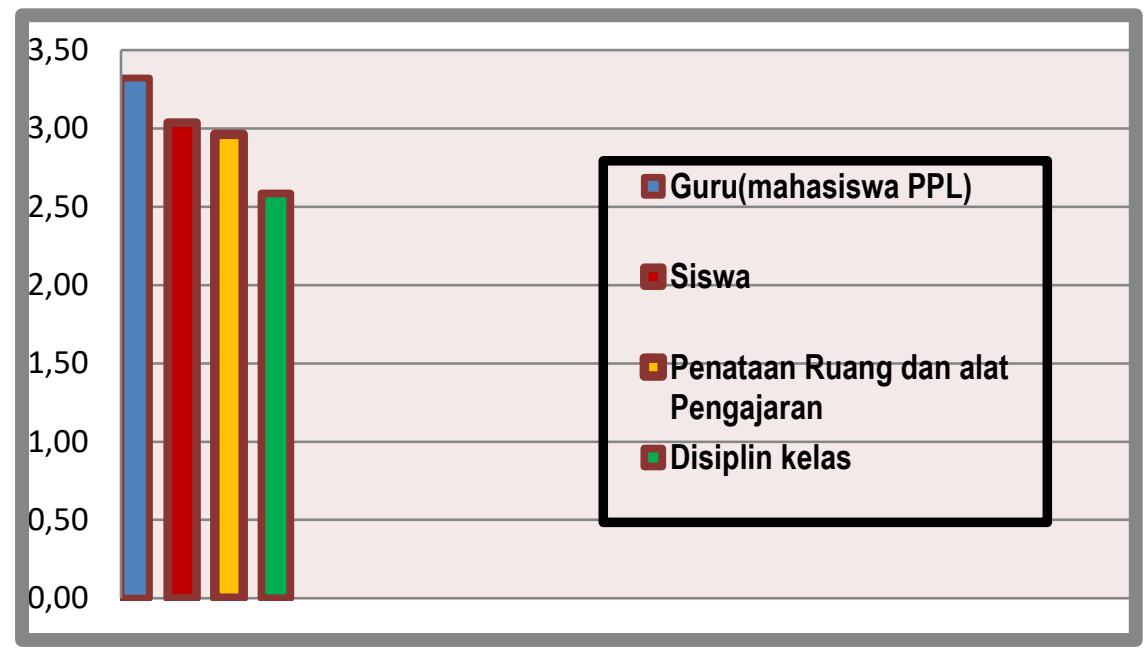

Gambar 1. Grafik Nilai Rerata Berbagai Indikator Hasil Penelititan

Berdasarkan hasil penelitian yang telah dilakukan, dapat disimpulkan bahwa kendala faktor pengelolaan kelas pada mata pelajaran bersifat teori yaitu berasal dari faktor sikap guru. Hal ini dapat disebabkan karena mahasiswa dalam pelaksanaan praktek mengajar belum memahami prinsip-prinsip guru dan sikap guru dalam pengelolaan kelas. Sebagai seorang guru PPL, mahasiswa belum dapat memberikan tanda-tanda yang menunjukan perhatian seorang guru kepada kelas yang dikelolanya. Sikap guru yang ditunjukkan di dalam kelas dan mahasiswa sebagai seorang guru belum dapat membagi perhatian yang rata kepada siswanya.

Apabila mahasiswa paham akan prinsip-prinsip dan tugas sebagai seorang guru dalam pengelolaan kelas dan kriteria dalam pengelolaan kelas, berbagai upaya untuk dapat mengelola kelas akan berjalan dengan baik sebagaimana yang diharapkan. Sehingga kelas akan berjalan kondusif serta efektif saat proses belajar mengajar. Sebaliknya, apabila mahasiswa sebagai seorang guru tidak memiliki sikap serta kemampuan mengelola kelas dengan baik, maka suasana belajar tidak berjalan dengan nyaman, dan itu arti-

nya tujuan pembelajaran tidak akan tercapai dengan maksimal.

Perbedaan Pembelajaran Menggunakan Aplikasi Multimedia Presentasi dengan Pembelajaran Media Program Pengolah Kata terhadap Hasil Belajar Mata Pelajaran Teori Kejuruan Teknik Furnitur (Studi pada Mata Pelajaran Kejuruan Furnitur Kelas XI SMKN 52 Jakarta) 


\section{KESIMPULAN}

Kesimpulan yang dapat diambil dari hasil penelitian ini bahwa faktor kendala dalam pelaksanaan pengelolaan kelas yang paling dominan yaitu faktor dari sikap guru terkait mahasiswa sebagai guru PPL. Faktor kendala pengelolaan kelas pada indikator sikap guru mempunyai nilai rerata pada hasil jawaban responden siswa mempunyai nilai rerata sebesar 3,32 . Secara terperinci, dapat dijabarkan sebagai berikut:

a. Pada sub indikator sikap guru yang mempunyai nilai tertinggi adalah sikap guru yang dapat memberikan penekanan pada hal positif kepada siswanya, mempunyai nilai sebesar 3,75 . Nilai terendah terdapat pada sub indikator sikap guru yang mampu bersikap luwes, mempunyai nilai sebesar 2,92. Hal ini menyatakan bahwa menurut responden siswa , guru PPL belum mampu untuk bersikap luwes didalam kelas.

b. Pada sub indikator siswa yang mempunyai nilai tertinggi adalah siswa yang diberi kesempatan untuk ikut dalam proses perencanaan kegiatan kelas mempunyai nilai sebesar 3,59. Nilai terendah terdapat pada sub indikator kerja sama siswa didalam kelas, mempunyai nilai sebesar 2,31. Dalam hal ini, guru PPL belum dapat mengembangkan kerja sama siswa didalam kelas untuk kegiatan kepentingan kelas.

c. Pada sub indikator penataan ruang dan alat pengajaran nilai terendah terdapat pada sub indikator penataan tempat duduk siswa,mempunyai nilai sebesar 1,91. Hal ini menyatakan bahwa guru PPL tidak pernah mengatur posisi tempat duduk siswa didalam kelas.

d. Pada sub indikator disiplin kelas nilai terendah terdapat pada sub indikator pengelolaan disiplin kelas oleh guru PPL, mempunyai nilai sebesar 2,08. Hal ini dapat dikatakan bahwa guru PPL belum bisa untuk mengatur kedisiplinan didalam kelas demi tercapainya pengelolaan kelas.

\section{Implikasi}

Berdasarkan hasil penelitian, tindak lanjut yang dapat diberikan adalah sebagai berikut :

a. Mahasiswa Program Studi Pendidikan Teknik Bangunan Jurusan Teknik Sipil UNJ perlu menyampaikan masalah dan kendala yang dihadapi dalam Program Pengalaman Lapangan khususnya dalam proses pengelolaan kelas kepada guru pamong atau dosen pembimbing .

b. Mahasiswa Program Studi Pendidikan Teknik Bangunan Jurusan Teknik Sipil UNJharus mempersiapkan diri dalam mengambil mata kuliah Program Pengalaman Lapangan.

c. Tugas dosen pembimbing PPL untuk lebih menjadikan Mahasiswa PPL yang lebih profesional dalam pelaksanaan mengelola kelas, khususnya dalam penerapan kedisiplinan didalam kelas, sehingga nantinya akan mempelancar pelaksaan tugasnya serta menghasilkan calon pendidik yang berkualitas.

\section{Saran}

Berdasarkan kesimpulan dan implikasi diatas dapat dikemukakan saran-saran sebagai berikut : 
a. Mahasiswa PPL harus mendapat perhatian yang sungguh-sungguh dari pihak jurusan, khususnya kendala mahasiswa dalam pengelolaan kelas, dengan cara pelatihan mengajar dan mengelola kelas mahasiswa PPL yang lebih sering.

c. Mahasiswa sebagai seorang guru PPL, dalam melakukan praktik mengajar perlu untuk memahami penciptaan dan pemeliharaan kondisi belajar yang optimal, seperti: menunjukan sikap tanggapnya seorang guru didalam kelas, membagi perhatian yang sama rata terhadap siswanya, berani untuk menegur dan memberikan hukuman kepada siswa yang bermasalah demi terciptanya kedisiplinan didalam kelas saat proses belajar mengajar

e. Pihak jurusan seharusnya lebih memperhatikan intensitas waktu dosen yang bersangkutan mengajar dikelas, agar mahasiswa tidak menjadi pihak yang dirugikan dalam hal ini

g. Dalam rangka meningkatkan sikap positif siswa terhadap mahasiswa PPL, hendaknya mahasiswa sebagai guru berusaha meningkatkan hubungan dan kerjasama dengan siswa melalui sistem pengajaran yang efektif. Hal ini dapat dilakukan dengan mengoptimalkan fungsi guru dalam pengelolaan kelas, menciptakan kondisi emosional dan kondisi fisik yang menguntungkan di dalam kelas, serta mengoptimalkan fungsi media pengajaran dengan baik

h. Bagi guru pamong dalam membimbing mahasiswa PPL hendaknya lebih intensif dan peka terhadap permasalahan yang dihadapi oleh mahasiswa PPL terutama dalam hal pengelolaan kelas

i. Penelitian ini masih terbatas pada deskriptif faktor kendala dalam pelaksanaan pengelolaan kelas, oleh karena itu perlu adanya penelitian lebih lanjut lagi pada masalah-masalah yang dihadapi oleh mahasiswa PPL dalam melaksanakan PPL.

\section{DAFTAR PUSTAKA}

Amirin, Tatang M. 2011. Populasi dan sampel penelitian 4: Ukuran sampel rumus Slovin. Tatangmanguny.wordpress.com

Boediono.2002.Kegiatan Belajar Mengajar.Jakarta: Puskur, Balitbang Depdiknas : dalam Makalah Kurikulum Berbasis Kompetensi.(Online).Tersedia. http ://www.or.id/data/BukuKBM.Pdf.[diakses 5 april 2012]

Buku Pedoman Skripsi/Komprehensif/Karya Inovatif(S1). Jakarta: FT UNJ Press.2009

Buku Pedoman Akademik (BPA). Jakarta: FT UNJ Press.2008

Buku Pedoman Program Pengalaman Lapangan (PPL). Jakarta: FT UNJ Press. 2010

Djaali dan Pudji Muljono.2008.Pengukuran dalam Bidang Pendidikan. Jakarta: Grasindo

Djamarah, dan Saiful Bahri.2010.Guru dan anak didik.Jakarta: PT Rineka Cipta

Perbedaan Pembelajaran Menggunakan Aplikasi Multimedia Presentasi dengan Pembelajaran Media Program Pengolah Kata terhadap Hasil Belajar Mata Pelajaran Teori Kejuruan Teknik Furnitur (Studi pada Mata Pelajaran Kejuruan Furnitur Kelas XI SMKN 52 Jakarta)

Hadi Mukhlish, T uti Iriani, R. Eka Murtinugraha 
Djamarah, Syaiful Bahri dan Aswan Zain. 2000. Guru dan Anak Didik Dalam Interaksi Edukatif. Jakarta: Rineka Cipta.

Herlina.2007. Pengaruh Pengelolaan Kelas Terhadap Hasil Belajar Biologi Siswa (Eksperimen di Kelas VII MTS. Al-Mafatih Palmerah).Skripsi,Jakarta:UIN

Isnanto, Eka A.2009.Manajemen kelas dalam mencapai Proses belajar mengajar Pendidikan agama islam Yang efektif Di sekolah menengah kejuruan SMK Negeri 2 malang.Skripsi.Malang:UIN

Kholik,Moh.2011.TeknikPengelolaanKelas.(Online).Tersedia.http://ainamulyana.blogspot.com/2012/02/me dia-pembelajaran.html [diakses pada 28 April 2012]

Nawawi, Hadari. 1986. Organisasi Sekolah dan Pengelolaan Kelas.Jakarta: PT. Gunung Agung

Rohani,Ahmad dan Abu Ahmadi. 1991. Pedoman Penyelenggaraan Administrasi Pendidikan Sekolah. Jakarta: Bumi Aksara

Rohani, Ahmad. 2004. Pengelolaan pembelajaran. Jakarta: PT. Rineka Cipta

Roestiyah, N.K. 2000.Masalah-Masalah IImu Keguruan.Jakarta: PT. Bina Aksara

Rusydie, Salman.2011.Prinsip-Prinsip Manajemen Kelas.Yogyakarta:Diva Press

Sanjaya,Wina.2007.Pembelajaran dalam Implementasi Kurikulum Berbasis Kompetensi,Jakarta : Kencana Prenada Media Grup

Sadiman, A. N.1993. Interaksi dan Motivasi Belajar Mengajar.Jakarta: PT. Raja

Grafindo Persada

Soekarno, Thomas. 1996. Manajemen Kelas dan Interaksi Manusiawi dalam Proses Belajar Mengajar.Semarang: IKIP Semarang PRESS.

Sudirman.1991. IImu Pendidikan. Bandung: Remaja Rosdakarya

Sugiyono. 2007. Metode Penelitian Pendidikan. Bandung : Alfabeta

Suharsimi, Arikunto. 1992. Pengelolaan Kelas dan Siswa Sebuah Pendekatan Evaluatif. Jakarta: Rajawali Press

Suharsimi,Arikunto. 2002. Prosedur Penelitian Suatu Pendekatan Praktek . Jakarta: Rineka Cipta

Sukayati.2011.Pengelolaan Kelas dan Penerapannya dalam PembelajaranKementrianPendidikanNasional.(Online).Tersedia.http://zonemakalah.blogspot. com/2012/03/fungsi-guru-dalam-pembelajaran.pdf [diakses 23 Maret 2012]

Sukewi. 1989. Pengelolaan Kelas. Semarang: IKIP Semarang PRESS.

Sukmadinata, Nana Syaodih. 2008. Metode Penelitian Pendidikan. Bandung :Remaja Rosdakarya.

Sunaryo.1989. Strategi Belajar Mengajar IImu Pengetahuan Sosial.Malang: IKIP Malang

Usman,Uzer. 2010. Menjadi Guru Profesional. Bandung: PT Remaja Rosdakarya

Undang-Undang RI No.20 Tahun 2003.Tentang Sistem Pendidikan Nasional.Bandung : Citra Umbara 
Wijaya, Cece \& Rusyan, Tabrani.1994. Kemampuan Dasar Guru dalam Proses Belajar Mengajar. Bandung: Remaja Rosdakarya 